\title{
Evaluation of the operational conditions in the production and morphology of Chlorella sp.
}

\author{
L. Rendón-Castrillón ${ }^{a *}$ (D), M. Ramírez-Carmona ${ }^{a}$ (D), C. Ocampo-López ${ }^{a}$ (D) and \\ R. Giraldo-Aristizabal ${ }^{a}$
}

${ }^{a}$ Centro de Estudios y de Investigación en Biotecnología - CIBIOT, Facultad de Ingeniería Química, Universidad Pontificia Bolivariana, Cir. 1ª \#70-01, of. Bloque 11-116, Medellín, Colombia

*e-mail: leidy.rendon@upb.edu.co

Received: September 17, 2019 - Accepted: October 01, 2019 - Distributed: February 28, 2021

(With 4 figures)

\begin{abstract}
It was evaluated the effect of operational conditions in the production of Chlorella sp. after its selection from genus Chlorella sp., Scenedesmus sp., Nannochloris sp., Tetraselmis sp. and Dunaliella salina. Microalgae were inoculated in drinking water with addition of NPK fertilizer ( $24 \%, \mathrm{P} 24 \%, \mathrm{~K} 18 \%$ ), at a concentration of $0.5 \mathrm{~g} / \mathrm{L}$, agitation of $150 \mathrm{rpm}$, temperature $25{ }^{\circ} \mathrm{C}$, light intensity of 1680 lumens at a color temperature of $6400 \mathrm{~K}$, without $\mathrm{pH}$ control for 8 days. The cellular concentrations obtained were $3.72 \times 10^{7}$ (Chlorella sp.), $1.36 \times 10^{7}$ (Scenedesmus sp.), $3.55 \times 10^{7}$

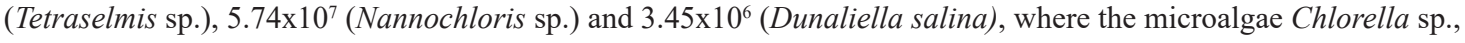
shows invasive capacity in drinking water cultivations. Applying the $2^{\text {n-p }}$ fractional factorial design concept for the elemental composition of the microalgae and the cellular morphology, it was obtained $44.33 \%$ of $\mathrm{C}, 7.09 \%$ of $\mathrm{H}, 8.53 \%$ of $\mathrm{N}$ and $0.84 \%$ of $\mathrm{S}$ for the Chlorella sp.
\end{abstract}

Keywords: biomass, microalgae, Chlorella sp, elemental analysis, morphology.

\section{Avaliação das condições operacionais na produção e morfologia de Chlorella sp.}

\section{Resumo}

Foi avaliado o efeito das condições operacionais na produção de Chlorella sp. após a seleção do gênero Chlorella sp., Scenedesmus sp., Nannochloris sp., Tetraselmis sp. e Dunaliella salina. Microalgas foram inoculadas em água potável com adição de fertilizante NPK (N 24\%, P 24\% e K 18\%), na concentração de 0,5 g/L, agitação de 150 rpm, temperatura de $25^{\circ} \mathrm{C}$, intensidade luminosa de 1.680 lúmens para uma temperatura de cor de $6.400 \mathrm{~K}$, sem controle de $\mathrm{pH}$ por 8 dias. As concentrações celulares obtidas foram de 3,72 x $10^{7}$ (Chlorella sp.), 1,36 x 10 $0^{7}$ (Scenedesmus sp.), $3,55 \times 10^{7}$ (Tetraselmis sp.), 5,74 x $10^{7}$ (Nannochloris sp.) e 3,45 x $10^{6}$ (Dunaliella salina), em que a microalga Chlorella sp. mostrou capacidade invasiva em cultivos de água potável. Aplicando o conceito de projeto fatorial fracionado $2^{\text {n-p }}$ para a composição elementar da microalga e a morfologia celular, foram obtidos $44,33 \%$ de C, 7,09\% de $\mathrm{H}, 8,53 \%$ de $\mathrm{N}$ e $0,84 \%$ de S para a Chlorella $\mathrm{sp}$.

Palavras-chave: biomassa, microalgas, Chlorella sp., análise elementar, morfologia.

\section{Introduction}

Microalgae constitute the base of the aquatic food chain (Vinitha and Jang-Seu, 2013), moreover they are considered as a promising raw material for food, feed, fuel, fertilizers, chemicals, and other value-added products, due to their rapid growth rates and its valuable intracellular components (Jing-Han et al., 2018).

It is estimated that microalgae exhibit higher biomass productivity than plants in terms of surface area needed for cultivation, and it is predicted that they represent a lower cost per yield (Bekirogullari et al., 2018; Chiu et al., 2015). In addition, microalgae have certain advantages compared to other crops, including a high growth rate, short growth time and low land use (Sanyano et al., 2013).

The algae have been exploited for more than a century as a source of colloids used as thickeners, gelling agents and stabilizers in the human and animal food industry. Due to its chemical composition, their applications comprise aquaculture, wastewater treatment (Jing-Han et al., 2018), energy production (Yang et al., 2018), (Bianchini et al., 2006), and cosmetics (Lee et al., 2018), (Spolaore et al., 2006). In addition, by its biotechnological potential, mainly due to the identification of various substances synthesized by these organisms (Becker, 2007), (Spolaore et al., 2006), 
(Cardozo et al., 2007) and (Bianchini et al., 2006), It is found extracted substances with commercial value such as: polyunsaturated fatty acids, carotenoids (Chen and Liu, 2018), phycobilins, polysaccharides, vitamins, sterols and several bioactive compounds (antioxidants, cholesterol reducers, among others). It can be used especially in the development of functional foods for its nutritional and pharmaceutical properties (Cardozo et al., 2007), (Becker, 2007), (Bianchini et al., 2006) and (Yañez, 2006).

In contrast, the energy content of microalgae biomass is formulated by the presence of carbon $(\mathrm{C})$, oxygen $(\mathrm{O})$, hydrogen $(\mathrm{H})$, nitrogen $(\mathrm{N})$ and other elements (Phukan et al., 2011). As a result, elemental analysis of biomass is being considered one of the most effective characterizations for any kind of possible energy generation from biomass including microalgae (Hossain et al., 2019).

Algae, like most marine organisms, need to develop and survive in a highly competitive environment, which, together with the fact that they do not have an immune system, leads the development of biochemical and physiological mechanisms from an evolutionary point of view to guarantee its survival (Hay, 2009), (López, 2008), (Cordeiro et al., 2017).

Due to its specific characteristics, Chlorella sp. have become one of the most researched microalgal groups by scientists due to their characteristics, including a high nutritional value in terms of natural antioxidants (Matsukawa et al., 2000), and lipid production (Zhu et al., 2014).

Previous studies have demonstrated that the composition of microalgae can be controlled by changing the growth medium and by culturing under different growth conditions (Azaman et al., 2017).

The morphology of microalgae is an important factor to evaluate and predict their behavior under different operational conditions; however, few studies are available correlating the elemental analysis of microalgae and operational conditions on the morphology.

To date, most studies microalgae have focused on the production of metabolites under different cultivation conditions, and research into the morphological of microalgae under various conditions is still lacking.

The main objectives of this study were: (i) to evaluate the adaptation of different microalgae, (ii) to conduct an evaluation about the effect of operational conditions on the morphology of Chlorella sp. microalgae and its elemental composition.

\section{Materials and Methods}

\subsection{Microalgae selection}

In this research, a set of fermentations were carried out using Chlorella sp., after its selection and evaluation from Chlorella sp., Scenedesmus sp., Nannochloris sp., Tetraselmis sp. and Dunaliella salina.

The microalgae were inoculated in $500 \mathrm{~mL}$ Erlenmeyer flask, containing drinking water with addition of NPK fertilizer (16-16-12), equivalent to $16 \%$ nitrogen, $16 \%$ phosphorus and $12 \%$ potassium, at a concentration of $0.5 \mathrm{~g} / \mathrm{L}$, stirring speed was $150 \mathrm{rpm}$, temperature $25^{\circ} \mathrm{C}$, light intensity of 1680 lumens at a color temperature of $6400 \mathrm{~K}$, without $\mathrm{pH}$ control, for 8 days.

Additionally, Dunaliella salina was supplemented with $35 \mathrm{~g} / \mathrm{L} \mathrm{NaCl}$ (100\% salinity), both Nannochloris and Tetraselmis with $10.5 \mathrm{~g} / \mathrm{L} \mathrm{NaCl}$ (30\% salinity).

In order to determine microalgal growth, it was carried out cell count by using a $0.100 \mathrm{~mm}$ Neubauer chamber and the number of cells per unit volume present in the cell suspension was reported (Ramírez et al., 2009). By the other hand, the affinity between the substrate and the microorganism was determined in the first stage of exponential growth as the slope of microalgal growth versus time (Quevedo, 2006).

\subsection{Fermentation}

The fermentation process was carried out by inoculating a $1000 \mathrm{~mL}$ Erlenmeyer flask with microalgae, the work volume was $600 \mathrm{~mL}$. The agitation, the $\mathrm{CO}_{2} /$ Air mixture aeration, the substrate concentration and the light for each of them were evaluated. The operational time of the fermentative process was 15 days. The initial $\mathrm{pH}$ was 5.04 and the temperature $25^{\circ} \mathrm{C}$. The tests were carried out applying a fractional factorial design with the factors at different levels as shown in Table 1 and 2.

Substrate $1\left(\mathrm{~S}_{1}\right)$ corresponds to a concentration equal to $1 \mathrm{~g} / \mathrm{L}$ of NPK (16-16-12) and Substrate $2\left(\mathrm{~S}_{2}\right)$ at a concentration equal to $0.5 \mathrm{~g} / \mathrm{L}$ of the same substrate.

As the NPK medium (16-16-12) did not contain a carbon source, the medium was supplemented with $0.1 \mathrm{vvm}$ (volume / (volume x min)) of $\mathrm{CO}_{2} /$ Air mixture as a source of carbon.

After selecting the microalgae, the growth of Chlorella sp. was evaluated indirectly by using the respirometric technique

Table 1. Operational conditions for the cultivation of algae, applying the concept of fractional factorial design.

\begin{tabular}{cccc}
\hline $\begin{array}{c}\text { Agitation } \\
(\mathbf{r p m})\end{array}$ & $\begin{array}{c}\text { Aeration } \\
(\mathbf{v v m})\end{array}$ & $\begin{array}{c}\text { Substrate } \\
(\mathbf{g} / \mathbf{L})\end{array}$ & $\begin{array}{c}\text { Light } \\
(\text { lumens })\end{array}$ \\
\hline 150 & 0.1 & 1 & 1680 \\
0 & 0.1 & 1 & 0 \\
0 & 0 & 1 & 1680 \\
0 & 0.1 & 0.5 & 1680 \\
0 & 0 & 0.5 & 0 \\
150 & 0 & 0.5 & 1680 \\
150 & 0.1 & 0.5 & 0 \\
150 & 0 & 1 & 0 \\
\hline
\end{tabular}

Agitation: 150 rpm, Light: Cool White lamp $6400 \mathrm{~K}$ (1680 lumens), Aeration $\mathrm{CO}_{2} /$ Air: $0.1 \mathrm{vvm}$ (volume / (volume x min)).

Table 2. Levels of the factors.

\begin{tabular}{ccccc}
\hline Level & $\begin{array}{c}\text { Agitation } \\
(\mathbf{r p m})\end{array}$ & $\begin{array}{c}\text { Aeration } \\
(\mathbf{v v m})\end{array}$ & $\begin{array}{c}\text { Substrate } \\
(\mathbf{g} / \mathbf{L})\end{array}$ & $\begin{array}{c}\text { Light } \\
(\text { lumens })\end{array}$ \\
\hline Upper & With & With & $\mathrm{S}_{1}(1)$ & With \\
& $(150)$ & $(0.1)$ & & $(1680)$ \\
Lower & Without & $\begin{array}{c}\text { Without } \\
(0)\end{array}$ & $\mathrm{S}_{2}(0.5)$ & $\begin{array}{c}\text { Without } \\
(0)\end{array}$ \\
& & & $(0)$ \\
\hline
\end{tabular}


on $\mathrm{S}_{1}$ and $\mathrm{S}_{2}$ substrates, in order to determine the adaptation and growth of the microalgae in these substrates.

A sample of $10 \mathrm{~mL}$ of the substrate was taken before being inoculated to evaluate the initial content of carbon, hydrogen, nitrogen, and sulfur. Then, a sampling of each test was done 15 days after fermentation; the samples were processed to quantify the biomass in terms of the content of the elements carbon, hydrogen, nitrogen and sulfur by elemental analysis and microscopic photography in order to evaluate the morphologic change.

\subsection{Biomass and supernatant quantification}

The samples obtained from the fermentation were centrifuged (Hettich, EBA 20) at $2000 \mathrm{rpm}$ for $10 \mathrm{~min}$. The biomass was separated from the supernatant and resuspended in distilled water. Therefore, a Neubauer counting chamber of $10^{-4} \mathrm{~cm}^{3}$ was used for the biomass counting in a microscope.

\subsection{Elemental Analysis (C, $H, N, S)$}

To quantify the content of carbon, hydrogen, nitrogen, and sulfur of the Chlorella sp. biomass, an Elemental Analyzer (Perkin Elmer, 2400 Series II CHON / S) was used. The samples were dried in a natural convection oven (Binder 23L), for 5 days at $50^{\circ} \mathrm{C}$ and then it was employed the modified method of Pregl-Dumas (Dynamic flash combustion), using Helium as the carrier gas.

\section{Results and Discussion}

\subsection{Selection of the microalgae}

Chlorella sp., Scenedesmus sp., Nannochloris sp., Tetraselmis sp. and Dunaliella salina were selected in this study due to its morphological differences and their potential applications at industrial scale.

The results obtained from cell counting for all the microalgae: Chlorella sp., Scenedesmus sp., Nannochloris sp., Tetraselmis sp. and Dunaliella salina are shown in Figure 1.

From Figure 1, it is generally observed that the microalgae adapted to the medium at evaluated conditions. The cellular concentrations were $3.72 \times 10^{7}$ (Chlorella $\mathrm{sp}$ ), $1.36 \times 10^{7}$ (Scenedesmus sp), 3.55 $\times 10^{7}$ (Tetraselmis $\mathrm{sp}$ ),

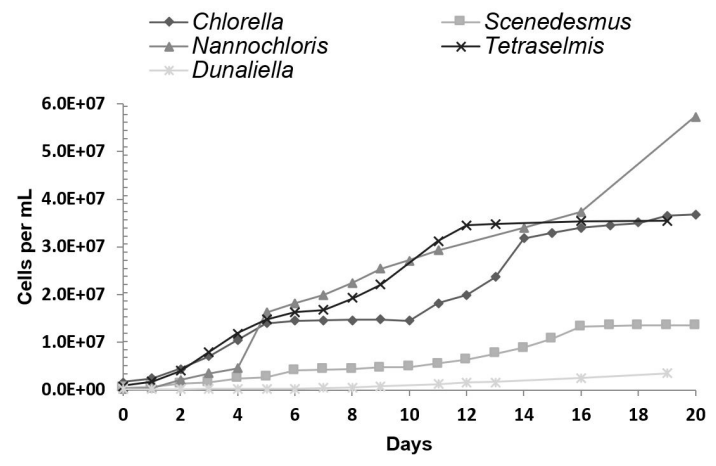

Figure 1. Comparison of the cellular count of microalgae in drinking water with the addition of NPK fertilizer (16-16-12).
$5.74 \times 10^{7}$ (Nannochloris sp) y $3.45 \times 10^{6}$ (Dunaliella salina). Although Tetraselmis sp. has a greater affinity for the culture medium evaluated, it is not the microalgae with greater cell growth. The greatest growth occurred with Nannochloris sp., though it showed less affinity $\left(1.00 \times 10^{6}\right)$. Of the evaluated microalgae, Chlorella sp. showed a better balance between affinity for the medium $\left(3.00 \times 10^{7}\right)$ and cell growth. The research results reported by Escudero show that strains of the genus Chlorella or Scenedesmus are generally used, because the microalgae of these genera show high growth rates even in open systems and are used in purification processes of effluents from both animal and industrial origin, appearing naturally in aquatic environments with minimal concentration of nutrients (Escudero, 2012).

Studies carried out by Ramírez et al. (2018) reported that the microalgae Nannochloris sp., Tetraselmis sp and Dunaliella salina, native to saline waters, do not adapt to mixed wastewater, even when it was supplemented with Sodium Chloride $(\mathrm{NaCl})$. This due to the presence of contaminants and a high organic load (830 ppm), so it shows a cellular decrease, while the algae Chlorella sp. and Scenedesmus sp. easily adapted to this type of water (Ramirez et al., 2018), (Chellappa et al., 2008). Likewise, Kim et al. (2007) reported the growth of Chlorella sp and Scenedesmus sp. in agro-industrial wastewater, assimilating the nutrients provided by the environment (Kim et al., 2007).

The adaptability of the microalgae to different culture media could facilitate or impede the process scale-up since the aim is to reduce costs by using economical culture media. Although Nannochloris sp. has a cellular growth of $20.2 \%$ above Chlorella sp., The culture medium for the microalgae Nannochloris sp., Tetraselmis sp, and Dunaliella salina are more demanding in terms of nutrients, therefore, it increases production costs at the industrial level.

Studies carried out by González show that Chlorella sp. is a cosmopolitan freshwater microalga of easy cultivation and rapid growth, which is improbable the risk of being contaminated by other types of algae (González, 2010). In addition, Chlorella vulgaris contains a high content of organic matter and possesses high photosynthetic activity (Kavitha et al., 2017). Besides, Chlorella sp. is the most popular strain in several applications, such as in biofuel, health food, cosmetics, and bioremediation (Hsieh et al., 2012). Figure 2 shows the invasive capacity of Chlorella sp. microalgae in drinking water with the addition of NPK fertilizer (16-16-12).

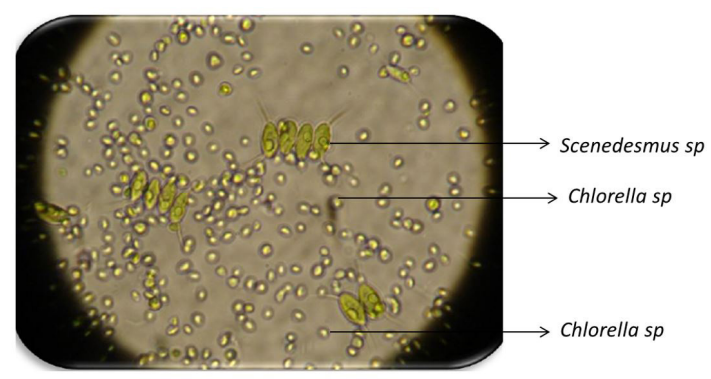

Figure 2. Microalgal growth. Culture contaminated with Chlorella sp. 
Studies carried out by Andrade et al., reported that Chlorella sp. culture has been used because of its protein quality and antitumor properties (Andrade et al., 2006). In addition, Chlorella sp. exhibits a high efficiency due to its easy adaptation to laboratory conditions and represents an ideal biological system for different areas of research (Morris Quevedo et al., 1999), (Ortega et al., 2004) and (Rendón et al., 2013).

\subsection{Fermentation}

In order to perform the fermentations tests it was applied the concept of fractional factorial design because, in industrial applications, it is common to find situations in which the factors affecting a process must be determined from a large number of possibilities. In this case, the application of replicated complete factorial designs is costly and unnecessary, and the sequential use of programmed fractional designs are recommended to identify the most significant effects, considerably reducing the number of experiments to be carried out (Juan and Peña, 1991).

Microalgae constitute an important group of photosynthetic organisms in the aquatic environment and are key players in the primary productivity and biogeochemical cycles. These organisms are highly diverse and sensitively respond to environmental changes. Some microalgae are grown well and are comparatively simple to culture under laboratory conditions. These characteristics make them an ideal model for monitoring both short and long-term environmental changes, as well as performing ecotoxicology assessments (Wang et al., 2018).

Microalgae are highly efficient producers of biomass because they have higher photosynthetic efficiency than land plants and undergo vigorous cell division (6-12 hours per cycle) under ideal growth conditions. Moreover, microalgae contain various bioactive compounds that can be utilized for numerous commercial uses (Sang-Il et al., 2019).

Different operational conditions were evaluated for the growth of Chlorella sp., due to the metabolic activities of the microalgae, which are highly versatile and flexible, which makes them adaptable to different culture conditions. This microalgae potential can be used to control and maximize the production of a specific component within the cell thereof (Bekirogullari et al., 2018).

In contrast, studies carried out by Sang-Il et al. (2019), showed that by evaluating different operating conditions such as the intensity of LED lights (blue, red, and white) on the cultivation of microalgae like $D$. salina, different beta-carotene productivity were obtained (Sang-Il et al., 2019). The responses of microalgae could include enhanced metabolism due to increased nutrient (Seung Won et al., 2010)

Additional studies showed that Chlorella strain hyper-accumulates lipids under high-salinity stress condition; however, it was found that the high-salinity condition significantly limited the production of algal biomass (Kakarla et al., 2018).

The results of the fermentations applying the design concept of growing experiments of Chlorella sp., as shown in Figure 3 and 4. In Figure 3, the results of the elemental analysis for experiments 1 to 8 for Chlorella sp. and in Figure 4, the morphology found in the culture media of the Chlorella sp. microalgae, a temperature of $25^{\circ} \mathrm{C}$ and pH: 5.04 .

The elemental CHN/S analysis is especially useful for microalgae due to the small amount of available sample, similar to that reported by Burczyk et al. (1999) in his study.

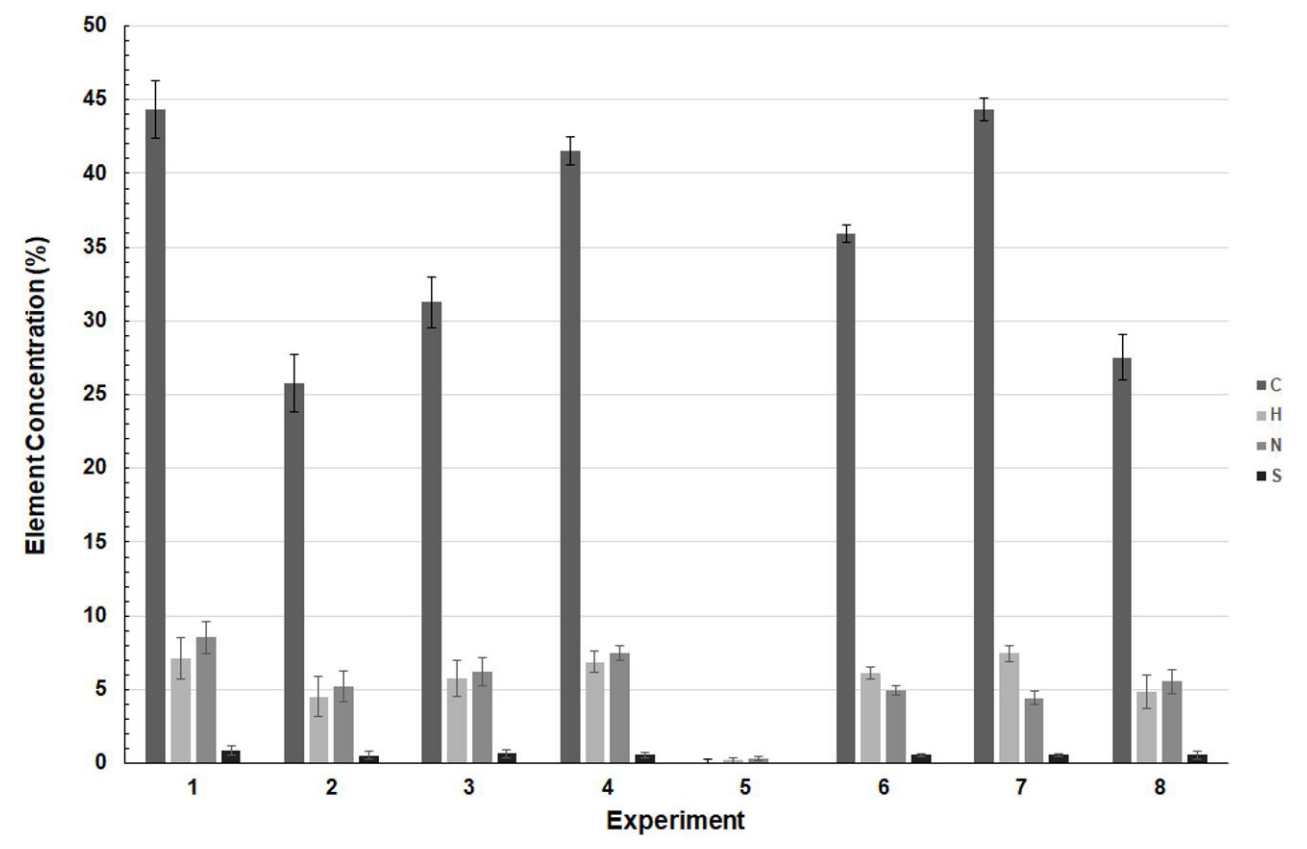

Figure 3. Elemental analysis of the dry microalgal biomass of Chlorella sp. 
Figure 3 shows the elemental analysis performed on the dry biomasses of the eight fermentations of Chlorella sp., where the availability of nutrients is observed as a factor that models their growth and different responses of biomass in relation to variations in the availability of the macronutrients carbon, phosphorus, and nitrogen.

According to the experiments, a better behavior is observed in the composition of the dry biomass of trial 1 , reporting $44.33 \%$ of $\mathrm{C}, 7.09 \%$ of $\mathrm{H}, 8.53 \%$ of $\mathrm{N}$ and $0.84 \%$ of $\mathrm{S}$, with a $\mathrm{C} / \mathrm{N}$ ratio of 5.2 , where the system preserves ideal conditions for the growth or production of biomass.

The results for experiment 5 show more limited conditions, with biomass showing low yield in its elemental composition, reporting $0.07 \% \mathrm{C}, 0.19 \% \mathrm{H}, 0.31 \% \mathrm{~N}$, and $0.00 \% \mathrm{~S}$ and a $\mathrm{C} / \mathrm{N}$ ratio from 0.22

Studies reported by Gopalakrishnan Kumar et al. (2018) in the cultivation of microalgae indicate that the $\mathrm{C} / \mathrm{N}$ ratio is an indicator for bioconversion reactions. The researchers found a $\mathrm{C} / \mathrm{N}$ ratio of 6.3 with a microalgal biomass concentration of $5 \mathrm{~g} / \mathrm{L}$. For other conditions evaluated, the $\mathrm{C} / \mathrm{N}$ ratio varied from 5.9 to 6.1 . The value of the $\mathrm{C} / \mathrm{N}$ ratio obtained from this study was similar to those reported in the literature on the cultivation of algae biomass Arthrospira platensis. In general, the microalgae biomass has a higher protein content instead of the carbohydrate content and its $\mathrm{C} / \mathrm{N}$ ratio is relatively lower than the macroalgal biomass, in which the maximum carbohydrate content is associated to the biomass (Gopalakrishnan et al., 2018).

Studies conducted for Chlorella $\mathrm{sp}$. showed values of $44.5 \%$ of $\mathrm{C}, 6.2 \%$ of $\mathrm{H}, 9.6 \%$ of $\mathrm{N}$ and a $\mathrm{C} / \mathrm{N}$ ratio of 4.63. These values are higher than those found in terrestrial plants (Thangalazhy-Gopakumar et al., 2012).

The results obtained in Figure 3 show that for experiments 1 and 4 the nitrogen content was either $8.53 \%$ or $7.48 \%$. Therefore, the amino acid or protein content in the biomass can be predicted. This fact agrees with the studies reported by Alhama et al., where they argue that amino acid biosynthesis is an important linkage between the metabolism of nitrogen and carbon in photosynthetic organisms, since the primary products of both assimilation pathways. Both ammonium and oxoacids, they are necessary to produce amino acids (Alhama et al., 1998).

Above mentioned coincides with studies carried out by González, in the influence of nitrogen and phosphorus deficiency in the competitive interactions between Chlorella vulgaris and Scenedesmus acutus, where it is shown that the effect of nutrient deficiency on growth is evident, especially when the limiting nutrient is nitrogen, regardless of the presence of phosphorus deficiency (González, 2010).

In Table 3 is presented the comparative elementary analysis of different Chlorella species obtained by Burczyk et al. (1999), the result of experiment 1 is also included.

The results reported in Table 3 show how the elemental composition of the experimental culture carried out in this research with Chlorella sp., stands out above the other crops evaluated, presenting a greater proportion of carbon, hydrogen, nitrogen, and sulfur. Although the Chlorella fusca shows a higher content of carbon (60.65\%) and hydrogen $(9.30 \%)$, Chlorella sp., shows a higher content of nitrogen $(8.53 \%)$ and sulfur $(0.84 \%)$.

It is observed how no species of Chlorella sp., from the reported ones, presents a concentration of sulfur in its elemental analysis, contrary to the experimentally evaluated culture that presents a percentage of sulfur, which is part of various organic compounds that include amino acids, proteins, coenzyme $\mathrm{A}$ and the Thiamin and Biotin Vitamins. Similarly, studies conducted by Morris Quevedo et al., argue that the amino acid composition of Chlorella vulgaris was comparable with the FAO reference protein, except for the low content of sulfur amino acids (Methionine and Cystine), a common phenomenon in these microorganisms (Morris Quevedo et al., 1999; Quevedo et al., 2008).

Under fluctuating conditions both inside and outside the cells, the species change their shape looking for a way to adapt to the different cultivation conditions such as agitation, aeration and light and they even change their morphology completely.

In the observations under the microscope, different proportions and morphologies were identified in the fermentations evaluated, as shown in Figure 4.

Regarding its morphology, the cell has slightly rigid walls and may also have sheets that cover the outside of the walls.

Organelles that contain pigments of chlorophyllides are called chloroplasts, a name that indicates that their predominant color is green (González Hurtado et al., 2002).

As can be observed in Figure 4, the most common shape found in the culture is rounded, some of them are amorphous, varying in color proportion and intensity. The experiment 1 that presented all the conditions and a higher proportion in macro and micronutrients is where a massive culture is observed, compared to the other

Table 3. Comparative elementary analysis of different Chlorella species.

\begin{tabular}{llccc}
\multicolumn{1}{c}{ MICROALGAE } & C (\%) & H (\%) & N (\%) & S (\%) \\
\hline Chlorella sp in this research* & 44.33 & 7.09 & 8.53 & 0.84 \\
Chlorella fusca & 60.65 & 9.3 & 3.35 & - \\
Chlorella pyrenoidosa A-24 & 39.74 & 5.58 & 5.26 & - \\
Chlorella saccharophila 211-1a & 39.18 & 5.97 & 0.2 & - \\
Chlorella sorokiniana 211-8k & 39.25 & 5.87 & 5.66 & - \\
Chlorella vulgaris Gromov 140 & 34.63 & 5.63 & 4.72 & - \\
\hline
\end{tabular}

\footnotetext{
* Test with best behavior: experiment 1 .
} 


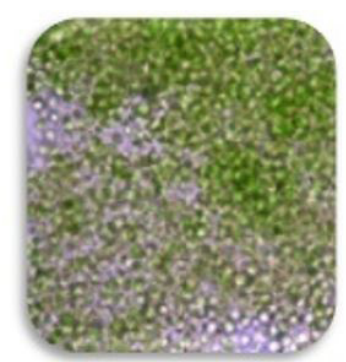

Experiment 1

$150 \mathrm{rpm}$
$0,1 \mathrm{vvm}$
$1 \mathrm{~g} / \mathrm{L}$

1680 Lumens



Experiment 5

$0 \mathrm{rpm}$
$0 \mathrm{vvm}$
$0,5 \mathrm{~g} / \mathrm{L}$
0 Lumens

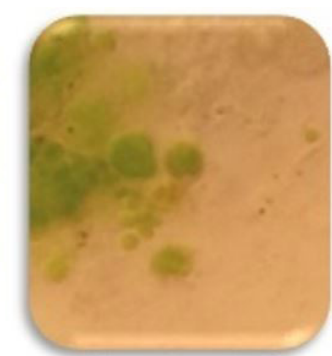

Experiment 2

$0 \mathrm{rpm}$
$0,1 \mathrm{vvm}$
$1 \mathrm{~g} / \mathrm{L}$
0 Lumens

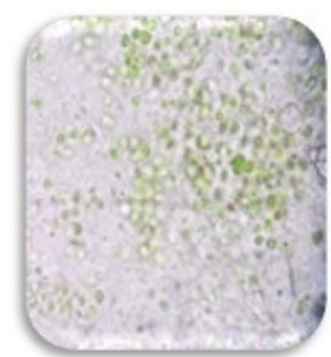

Experiment 6

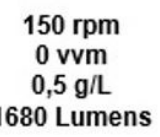

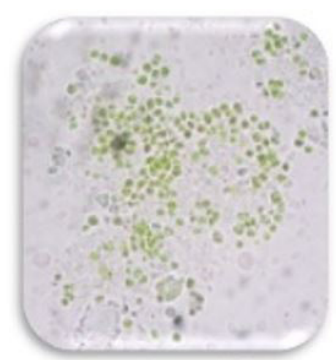

Experiment 3

$0 \mathrm{rpm}$

$0 \mathrm{vvm}$

$1 \mathrm{~g} / \mathrm{L}$

1680 Lumens

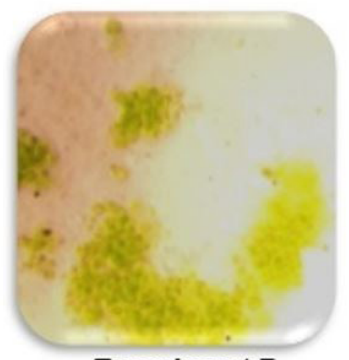

Experiment 7

$150 \mathrm{rpm}$

$0,1 \mathrm{vvm}$

$0,5 \mathrm{~g} / \mathrm{L}$

0 Lumens

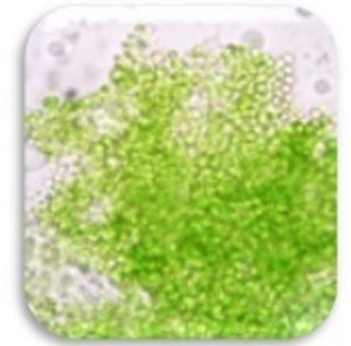

Experiment 4

$0 \mathrm{rpm}$

$0,1 \mathrm{vvm}$

$0,5 \mathrm{~g} / \mathrm{L}$

1680 Lumens

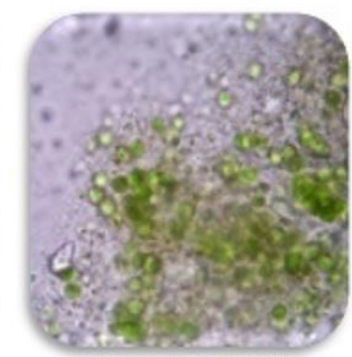

Experiment 8

$150 \mathrm{rpm}$

$0 \mathrm{vvm}$

$1 \mathrm{~g} / \mathrm{L}$

0 Lumens

Figure 4. Morphologies found in the culture media of the Chlorella sp. microalgae, at a temperature of $25^{\circ} \mathrm{C}$ and $\mathrm{pH} 5.04$.

experiments where there is an absence of a certain factor or condition (Câmara et al., 2015).

Studies report that high concentrations of nutrients in the medium cause the cells tend to increase their sphericity more than normal, producing an increase in the surface / volume ratio, which favors the incorporation of nutrients and an increase in the concentration of chloroplasts, which allows to the cells a greater uptake of light (Acevedo and Ramírez, 2003).

\section{Conclusion}

It was observed that the microalgae adapted to both the culture medium and the conditions evaluated. The cell concentrations presented were $3.72 \times 10^{7}$ (Chlorella $\mathrm{sp}$ ), $1.36 \times 10^{7}$ (Scenedesmus sp), 3.55 $\times 10^{7}$ (Tetraselmis $\mathrm{sp}$ ), $5.74 \times 10^{7}$ (Nannochloris sp) and $3.45 \times 10^{6}$ (Dunaliella salina), where the microalga Chlorella sp., shows the capacity of being invasive and polluting in drinking water cultivations.

The ideal conditions for the production of microalgal biomass are $150 \mathrm{rpm}, 0.1 \mathrm{vvm}, 1 \mathrm{~g} / \mathrm{L}$ and 1680 lumens, obtaining $44.33 \%$ of $\mathrm{C}, 7.09 \%$ of $\mathrm{H}, 8.53 \%$ of $\mathrm{N}$ and $0.84 \%$ of $\mathrm{S}$ in the dry biomass. The content of $\mathrm{C} / \mathrm{N} / \mathrm{P}$ affects the morphology of the microalgae.

\section{Acknowledgements}

The authors express their gratitude for the financial support received by the EPM Company and the Universidad Pontificia Bolivariana (UPB) in the development of this research.

\section{References}

ACEVEDO, A. and RAMÍREZ, J., 2003. Influencia de un gradiente cruzado de luz y temperatura en la morfología de Scenedesmus acutus meyen var. globosus hortobágyi y sus implicaciones taxonómicas. Actualidades Biologicas, vol. 25, pp. 141-146.

ALHAMA, J., LÓPEZ, A., DIEZ, J. and GARCÍA, J., 1998. Effect of carbon and nitrogen availability on intracellular amino acids and ammonium pools in the green alga Monoraphidium braunii. Journal of Plant Physiology, vol. 153, pp. 529-533.

ANDRADE, R., TORRES, R., MONTES, E. and FERNÁNDEZ, A., 2006. Obtención de harina a partir del cultivo de Chlorella vulgaris y su análisis proteico. Departamento de Ingeniería de Alimentos., vol. 12, pp. 1-8.

AZAMAN, S., NAGAO, N., YUSOFF, F., TAN, S. and YEAP, S., 2017. A comparison of the morphological and biochemical characteristics of Chlorella sorokiniana and Chlorella zofingiensis cultured under photoautotrophic and mixotrophic conditions. PeerJ, vol. 5, pp. 1-22. PMid:28929006. 
BECKER, E.W., 2007. Micro-algae as a source of protein. Biotechnology Advances, vol. 25, no. 2, pp. 207-210. PMid:17196357.

BEKIROGULLARI, M., PITTMAN, J. and THEODOROPOULOS, C., 2018. Multi-factor kinetic modelling of microalgal biomass cultivation for optimised lipid production. Bioresource Technology, vol. 269, pp. 417-425. PMid:30265993.

BIANCHINI, R., OHSE, S., VILLELA, M., CARVALHO, S.M. and FETT, R., 2006. Microalgas, produtos e aplicações. Ciência Rural, vol. 366, pp. 1959-1967.

BURCZYK, J., ŚMIETANA, B., TERMIŃSKA, K., ZYCH, M. and KOWALOWSKI, P., 1999. Comparison of nitrogen content amino acid composition and glucosamine content of cell walls of various chlorococcalean algae. Phytochemistry, vol. 51, pp. 491-497.

CÂMARA, F.R.A., ROCHA, O., PESSOA, E.K.R., CHELLAPPA, S. and CHELLAPPA, N.T., 2015. Morphofunctional changes of phytoplankton community during pluvial anomaly in a tropical reservoir. Brazilian Journal of Biology $=$ Revista Brasileira de Biologia, vol. 75, no. 3, pp. 1-10.

CARDOZO, K., GUARATINI, T., BARROS, M.P., FALCÃO, V.R., TONON, A.P., LOPES, N.P., CAMPOS, S., TORRES, M.A., SOUZA, A.O., COLEPICOLO, P. and PINTO, E., 2007. Metabolites from algae with economical impact. Comparative Biochemistry and Physiology. Toxicology \& Pharmacology, vol. 146, no. 1-2, pp. 60-78. PMid:16901759.

CHELLAPPA, N.T., BORBA, J.M. and ROCHA, O., 2008. Phytoplankton community and physical-chemical characteristics of water in the public reservoir of Cruzeta, RN, Brazil. Brazilian Journal of Biology $=$ Revista Brasileira de Biologia, vol. 68, no. 3, pp. 477-494. PMid:18833468.

CHEN, C.Y. and LIU, C.C., 2018. Optimization of lutein production with a two-stage mixotrophic cultivation system with Chlorella sorokiniana MB-1. Bioresource Technology, vol. 262, pp. 74-79. PMid:29698840.

CHIU, S.Y., KAO, C.Y., CHEN, T.Y., CHANG, Y.B., KUO, C.M. and LIN, C.S., 2015. Cultivation of microalgal Chlorella for biomass and lipid production using wastewater as nutrient resource. Bioresource Technology, vol. 184, pp. 179-189. PMid:25499744.

CORDEIRO, R.S., BARBOSAA, J.E.L., LIMA FILHOA, G.Q. and BARBOSA, L.G., 2017. Periphytic algae dynamics in lentic ecosystems in the Brazilian semiarid. Brazilian Journal of Biology = Revista Brasileira de Biologia, vol. 77, no. 3, pp. 495-505.

ESCUDERO, R., 2012. Planta de producción de microalgas con fines energéticos. Almería, España: Universidad de Almería. M.Sc Thesis

GONZÁLEZ HURTADO, M., QUINTANA AMADOR, I. and RODRÍGUEZ ACOSTA, C., 2002. Comparación Química entre dos fertilizantes ecológicos de origen natural. Revista CENIC Ciências Quimicas, vol. 33, no. 1, pp. 11-13.

GONZÁLEZ, L.M., 2010. Influencia de la deficiencia de Nitrógeno y Fósforo en las interacciones competitivas entre Chlorella vulgaris y Scenedesmus acutus. Colombia: Universidad Nacional de Colombia. M.Sc Thesis

GOPALAKRISHNAN, K., DINH DUC, N., PERIYASAMY, S., TAKURO, K., KAIQIN, X. and SOON WOONG, C., 2018. Cultivation of microalgal biomass using swine manure for biohydrogen production: Impact of dilution ratio and pretreatment. Bioresource Technology, vol. 260, pp. 16-22.

HAY, M., 2009. Marine chemical ecology: Chemical signals and cues structure marine populations, communities, and ecosystems. Annual Review of Marine Science, vol. 1, pp. 193212. PMid:21141035

HOSSAIN, N., ZAINI, J., MAHLIA, T. and AZAD, A.K., 2019. Elemental, morphological and thermal analysis of mixed microalgae. Renewable Energy, vol. 131, pp. 617-624.

HSIEH, H.J., SU, C.H. and CHIEN, L.J., 2012. Accumulation of lipid production in Chlorella minutissima by triacylglycerol biosynthesis-related genes cloned from Saccharomyces cerevisiae and Yarrowia lipolytica. Journal of Microbiology, vol. 50, no. 3, pp. 526-534. PMid:22752918.

JING-HAN, W., ZHUANG, L.L., XU, X.Q., DEANTESESPINOSA, V.M., WANG, X.X., and HU, H.Y., 2018. Microalgal attachment and attached systems for biomass production and wastewater treatment. Renewable \& Sustainable Energy Reviews, vol. 92, pp. 331-342.

JUAN, J. and PEÑA, D., 1991. Analisis de diseños factoriales sin replicación. Trabajos de Estadistica, vol. 6, pp. 63-80.

KAKARLA, R., CHOI, J.W., YUN, J.H., KIM, B.H., HEO, J., LEE, S., CHO, D.H., RAMANAN, R. and KIM, H.S., 2018. Application of high-salinity stress for enhancing the lipid productivity of Chlorella sorokiniana HS1 in a two-phase process. Journal of Microbiology, vol. 56, no. 1, pp. 56-64. PMid:29299841.

KAVITHA, S., SUBBULAKSHMI, P., RAJESH BANU, J., GOBI, M. and TAE YEOM, I., 2017. Enhancement of biogas production from microalgal biomass through cellulolytic bacterial pretreatment. Bioresource Technology, vol. 233, pp. 34-43. PMid:28258994.

KIM, M.K., PARK, J.W., PARK, C.S., KIM, S.J., JEUNE, K.H., CHANG, M.U. and ACREMAN, J., 2007. Enhanced production of Scenedesmus sp. green microalgae using a new medium containing fermented swine wastewater. Bioresource Technology, vol. 98, no. 11, pp. 2220-2228. PMid:17081748.

KUMAR, G., NGUYEN, D.D., SIVAGURUNATHAN, P., KOBAYASHI, T., XU, K. and CHANG, S.W., 2018. Cultivation of microalgal biomass using swine manure for biohydrogenproduction: impact of dilution ratio and pretreatment. Bioresource Technology, vol. 260, pp. 16-22. PMid:29604564.

LEE, J., KIM, D.S., YANG, J.H., CHUN, Y., YOO, H.Y., HAN, S.O., LEE, J., PARK, C. and KIM, S.W., 2018. Enhanced electron transfer mediator based on biochar from microalgal sludge for application to bioelectrochemical systems. Bioresource Technology, vol. 264, pp. 387-390. PMid:30041774.

LÓPEZ, F., 2008. Estudio de las algas. Innovación y Experiencias Educativas, vol. 8, pp. 2-8.

MATSUKAWA, R., HOTTA, M., MASSUDA, Y., CHIHARA, M. and KARUBE, I., 2000. Antioxidants from carbon dioxide fixing Chlorella sorokiniana. Journal of Applied Phycology, vol. 12, pp. 263-267.

MORRIS QUEVEDO, H.J., QUINTANA CABRALES, M.M., ALMARALES ARCEO, A. and HERNÁNDEZ NAZARIO, L., 1999. Composición bioquimica y evaluación de la calidad proteica de la biomasaautotrofica de Chlorella vulgaris. Alimentos e Nutrição, vol. 13, no. 2, pp. 123-131.

ORTEGA, J., TEMPLE, S., BAGGA, S., GHOSHROY, S. and SENGUPTA-GOPALAN, C., 2004. Biochemical and molecular characterization of transgenic Lotus japonicus plants constitutively over-expressing a cytosolic glutamine synthetase gene. Planta, vol. 219, no. 5, pp. 817-818. PMid:15197594. 
PHUKAN, M.M., CHUTIA, R.S., KONWAR, B.K. and KATAKI, R., 2011. Microalgae Chlorella as a potential bio-energy feedstock. Applied Energy, vol. 10, pp. 3307-3312.

QUEVEDO, C., 2006. Selección de un medio de cultivo para la producción de proteína microalgal a partir de Scenedesmus $s p$. Bogotá, Colombia: Universidad Nacional de Colombia, pp. 1-120. Chem. Eng Thesis.

QUeVEDO, C., MORAlES, S. P. and ACOSTA, C., 2008. Crecimiento de Scenesmus spen diferentes medios de cultivo para la producción de proteína microalgal. Vitae. Revista de la Facultad de Química Farmacéutica, vol. 15, pp. 25-31.

RAMÍREZ, M., CARDONA, M., CASAS, A., TORRES, M., OCAMPO, C., VASCO, O., OVIEDO, J., MAYA, M., VANEGAS, D. and VELEZ, Y., 2009. Manual de laboratorio Biotecnología Ambiental. Medellín: Editorial Universidad Pontificia Bolivariana.

RAMIREZ, M.E., VÉLEZ, Y.H., RENDÓN, L. and ALZATE, E., 2018. Potential of microalgae in the bioremediation of water with chloride content. Brazilian Journal of Biology $=$ Revista Brasileira de Biologia, vol. 78, no. 3, pp. 472-476. PMid:29069164.

RENDÓN, L., RAMÍREZ, M. and VÉLEZ, Y., 2013. Microalgas para la industria alimenticia. Medellín: Universidad Pontificia Bolivariana.

SANG-IL, H., SOK, K., CHANGSU, L. and YOON-E, C., 2019. Blue-Red LED wavelength shifting strategy for enhancing beta-carotene production from halotolerant microalga, Dunaliella salina. Journal of Microbiology, vol. 57, no. 2, pp. 101-106. PMid:30556108.

SANYANO, N., CHETPATTANANONDH, P. and CHONGKHONG, S., 2013. Coagulation-flocculation of marine Chlorella sp. for biodiesel production. Bioresource Technology, vol. 147, pp. 471-476. PMid:24012844.

SEUNG WON, J., JOON SANG, P., OH YOUN, K. and JUNG-HOON, K., 2010. Effects of crude oil on marine microbial communities in short term outdoor microcosms. Journal of Microbiology, vol. 48, no. 5, pp. 594-600. PMid:21046336.

SPOLAORE, P., JOANNIS-CASSAN, C., DURAN, E. and ISAMBERT, A., 2006. Commercial applications of Microalgae. Journal of Bioscience and Bioengineering, vol. 1012, no. 2, pp. 87-96. PMid:16569602.

THANGALAZHY-GOPAKUMAR, S., ADHIKARI, S., CHATTANATHAN, S.A. and GUPTA, R.B., 2012. Catalytic pyrolysis of green algae for hydrocarbon production using H+ZSM-5 catalyst. Bioresource Technology, vol. 118, pp. 150157. PMid:22705518.

VINITHA, E. and JANG-SEU, K., 2013. Quantification of toxic effects of the herbicide metolachlor on marine microalgae Ditylum brightwellii Bacillariophyceae, Prorocentrum minimum Dinophyceae, and Tetraselmis suecica Chlorophyceae. Journal of Microbiology, vol. 51, no. 1, pp. 136-139. PMid:23456723.

WANG, H., EBENEZER, V. and KI, J.S., 2018. Photosynthetic and biochemical responses of the freshwater green algae Closterium ehrenbergii Meneghini Conjugatophyceae exposed to the metal coppers and its implication for toxicity testing. Journal of Microbiology, vol. 56, no. 6, pp. 426-434. PMid:29858831.

YAÑEZ, M., 2006. Desnutrición infantil en América Latina y el Caribe. Desafios: Boletín de la infancia y la adolescencia sobre el avance de los objetivos de desarrollo del Milenio. no. 2, pp. 1-12.

YANG, L., WANG, L., ZHANG, H., LI, C., ZHANG, X. and HU, Q., 2018. A novel low cost microalgal harvesting technique with coagulant recovery and recycling. Bioresource Technology, vol. 266, pp. 343-348. PMid:29982056.

ZHU, S., HUANG, W., XU, J., WANG, Z. and YUAN, Z., 2014. Metabolic changes of starch and lipid triggered by nitrogen starvation in the microalga Chlorella zofingiensis. Bioresource Technology, vol. 152, pp. 292-298. PMid:24308944. 